\title{
ON THE BENEFICIARY INSCRIPTIONS IN THE SOUTH OF THE PROVINCE OF MOESIA SUPERIOR (The Examples from Kosovo and Metohija)
}

ABSTRACT. The paper presents data on consular beneficiary stations in Kosovo and Metohija (the south of the province of Moesia Superior). It is about beneficiary inscriptions which were found near roads which intersected Kosovo and Metohija from the north to south areas (Narona-Scupi) and from the southwest to northeast areas (Lissus-Naissus). Consular beneficiries were legionaries legio VII Claudiae and legio IV Flaviae in these stations. A critical review of the function and the position of consular beneficiaries, who were the guardians of public safety, is given as well.

KEYWORDS: beneficiaries, inscriptions, legions, Moesia Superior, Kosovo and Metohija.

A significant number of epigraph statues testifies to the Roman rule in the south of the province of Moesia Superior. The epigraph statues and records on consular beneficiaries in Kosovo and Metohija (beneficiarii consularis) are highly significant for us (Caver, 1881,

1

gligorijas@yahoo.com

The paper presents the results of research conducted under the Projekt № III 47023 Kosovo and Metohija between national identity and European integration, which is funded by the Ministry of Education, Science and Technological Development of the Republic of Serbia. 
pp. 379-401; Domaszevski, 1895, p. 98; Domaszevski, 1902, pp. 158211; Domaszewski, 1904, pp. 14-19; Filow, 1906, p. 89; Čerškov, 1969, pp. 57-58, 96-97; Мирковић, 1971, р. 268; Папазоглу, 1988, pp. 163164; Фидановски, 1989, pp. 303-306; Mirdita, 2015, pp. 222-229). Besides a highly significant number of found epigraph statues, there is still an open question of the function of consular beneficiaries, which was thoroughly researched for the first time by O. Hirschfeld and A. Domaszewski in 1891 and 1902 (Hirschfeld, 1891, pp. 844-877; Domaszewski, 1902, pp. 158-211). The end of the $20^{\text {th }}$ century marks a significant progress with regard to this topic and its research, which can be proved by a number of different academic papers and books with corpora consisting of beneficiary inscriptions even from the province of Moesia Superior (CBFIR 1990; Мирковић, 1971, pp. 263-271; Rankov, 1987, p. 6; Фидановски, 1989, pp. 303-306; Schallmayer, 1991, pp. 400-406; Mirković, 1991, pp. 252-256; Ott, 1995, pp. 82-150; Dise, 1995, pp. 72-85; Dise, 1996, pp. 286-292; Dise, 1997, pp. 284-299; Rankov, 1999, pp. 15-35; Mirdita, 2015, pp. 222229).

Because it is a general term, it is diffcult to determine more precisely the role of the consular beneficiaries, which, even today, opens many scientific discussions on various questions regarding the term. It is thought that the consular beneficiaries were legionaries who were put under the rule of a province's envoy after being transfered from their legions. They reported to the province's envoy directly. According to the epigraph records, it is thought as well that beneficiarii consularis were used as soldiers who performed numeros and various duties for the province's envoy (Mirković, 1991, pp. 255-256; Schallmayer, 1991, pp. 400-406; Ott, 1995, pp. 82154; Dise, 1995, pp. 72-85; Rankov, 1999, pp. 27-29; Glavaš, 2013, pp. 64-65; Glavaš, 2015, p. 8; Mirdita, 2015, pp. 222-229; Glavaš, 2016, pp. 10-12). The position of consular beneficiaries on the roads, mostly along the border provinces, points to the fact that their function was a part of the organised administrative system of the province. They spent mostly six months or a year in the stations and left votaries mostly dedicated to Jupiter in religious places in the station compund. These votaries were set there upon their arrival or departure (expleta statione, exacta statione, accepta missione) (Nelis-Clement, 1994, p. 252; Dise, 1997, pp. 286-292; Rankov, 1999, pp. 27-29; Glavaš, 2013, pp. 64-65; Mirdita, 2015, pp. 222-229; Glavaš, 2016, pp. 10-12). 
The consular beneficiaries were representatives of the province's envoy when interacting with the local population. That is the reason why every interaction of the locals with the executive power was mostly initiated or done with the help of the beneficiaries. Therefore, the province's envoy showed his presence indirectly on all significant locations determined by him whether they were roads, transport routes, road intersections, mines, border areas or significant urban centers. Since the consular beneficiaries were usually legionaries, their transfer to various provinces had its significance in terms of safety. The number of consular beneficiary stations increased since the Makroman crisis in 190 and the presence along strategic roads in provinces, even in Moesia Superior (Mirković, 1971, pp. 269-271; Фидановски, 1989, pp. 303-306; Schallmayer, 1991, p. 403; Dise, 1995, p. 79; Mirdita, 2015, pp. 222229; Glavaš, 2016, pp. 10-12).

Therefore, beneficiary stations were placed at the more significant places and stops in the province of Moesia Superior. They got their names depending on the fact who gave them their authority and rights. They were given the right to command smaller military units located at strategically significant points. The main duty of the soldiers who served there was primarily to maintain order and to secure transport. Their presence on different roads was influenced by the need to ensure the safety of those who traveled, transported mine ores, agricultral and other products. Besides their duties to protect and enable the safety of those who traveled, free trade at various road points and customs points, they also collected taxes. Consular beneficiaries had other military and administrative duties and that is why their inscritpions can be seen as related to them. Therefore, researchers should be careful with statues found in bigger cities while everything is much clearer with statues found in villages or outside of military camps (Mcmullen, 1963, pp. 58-59; Mirković, 1971, pp. 269-271; Фидановски, 1989, pp. 303-306; Schallmayer, 1991, pp. 403; Nelis-Clement, 1994, pp. 252; Dise, 1995, p. 79; Dise, 1997, pp. 286-292; Rankov, 1999, pp. 27-29; Glavaš, 2013, pp. 64-65; Mirdita, 2015, pp. 222-229; Glavaš, 2016, pp. 10-12).

The military class of society, which inhabited the area due to the state interests, was a distinct class of the population in Kosovo and Metohija. The low-level officers, consular beneficiaries, and military personnel from Mezija legion were the members of this class. It is thought that they were transfered from VII Claudia camp to Viminacium and IV Flavia to Singidunum and to certain other sta- 
tions, which were located along the two main roads: Narona-Scupi and Lissus-Naissus. (Tab. Peut. 468, 469, 557, 558; It. Ant. 338; Čerškov, 1969, pp. 57-58, 96-97; Мирковић, 1971, pp. 268; Папазоглу, 1988, pp. 163-164; Фидановски, 1989, pp. 303-306; Mirdita, 2015, pp. 222-229). The main road which led through the inland of the province of Dalmatia and Moesia Superior, i.e. from Narona to Skoplje (through Gacko, Foča, Novi Pazar, Kosovska Mitrovica, and Priština) was the place where records of consular beneficiaries were found near Novi Pazar, in Slatina village, Kosovska Mitrovica, Vučitrn in the valley of Ibar and Sitnica as well as in Kačanik in the valley of Lepenac (Evans, 1885, p. 74 fig. 39; Вулић, 1931, p. 42 Sp. 96,81 № 208 , 90 № 209 , 91 № 210 , 91 № 211,102 № 223,133 № 321, 135 № 325, 192 № 513; Čerškov, 1969, pp. 57-58, 96-97; Мирковић, 1971, р. 268; Папазоглу, 1988, pp. 163-164; Фидановски, 1989, pp. 303-306; Mirdita, 2015, pp. 222-229). The other road, Lissus-Naissus, was the place where the records were found in Dobružde village, Prizren, as well as two beneficiary inscriptions from speculatores from Priština and in Batusa village (Čerškov, 1969, pp. 57-58, 96-97; Мирковић, 1971, р. 368; Фидановски, 1989, pp. 303-306). Thanks to the position of a beneficiary, i.e. to the process of going up the service ladder, they were able to reach the rank of speculatores, becoming in that way principales in the office of the province's envoy (Мирковић, 1971, p. 268). Principales were wealthier than ordinary soldiers becuase they were paid one and a half or two times more. The members of the province's envoy's unit, i.e. high-level officers such as cornicularii, speculators, beneficiarii consularis, frumentarii, stratores consularis recieved the salary which was double what the ordinary soldiers received (Мирковић, 1971, p. 268; Ferjančić, 2010, p. 135; Matijević, 2012, pp. 69-71).

Two inscriptions prove the existance of the station protected by a smaller unit under the command of consular beneficiaries near Novi Pazar. One was saved on an ara $(0,84 \times 0,32 \times 0,28 \mathrm{M})$, which was found in Novi Pazar Banja, 5 kilometers away from Novi Pazar (Марић, 1956, pp. 356-358; Мирковић, 1971, р. 263). I(ovi) o(ptimo) $\mathrm{m}$ (aximo) / ceterisque / dis deabus / huiusce / loci pro salute / domini nostri / M(arcus?) Ucenteus / b(ene)f(iciarius) c(onsularis) l(egionis) VII $\mathrm{Cl}$ (audiae) / v(otum) s(olvit). The inscription dates back to the $3^{\text {rd }}$ century (ILJug $67=$ CBFIR 595). The second inscription was found on an ara $(0,99 ? 0,36$ ?) built into a wall of St. Peter's Chruch, 3 kilometers away from Novi Pazar, on the way to Raška (Мирковић, 1971, pp. 263-364). [I(ovi) o(ptimo) m(aximo)]/ ceterisq(ue)/dis dea/busque / 
huiusq(ue) / loci M(arcus) Victorius / Urcianus b(ene)f(iciarius) co(n)s(ularis) / le[g(ionis) VII Cl(audiae)] pos(uit). The inscription dates back to the second half of the $2^{\text {nd }}$ and the beginning of the $3^{\text {rd }}$ century (CBFIR 596; Мирковић, 1971, p. 264).

An ara $(0,36 \times 0,30 \mathrm{M})$ was found in Slatina village near Sočanica with the inscription (Вулић, 1931, p. 102 № 223). I(ovi) o(ptimo) m(aximo) et Nemesi / reg(inae) Genio / stat(ionis) m(unicipii?) Dard(anorum) / Sep(timius) Vitalis / b(ene)f(iciarius) co(n)s(ularis) leg(ionis) / VII Cl(audiae) v(otum) l(ibens) s(olvit) (ILJug 69 = CBFIR 602). The inscription dates back to the $3^{\text {rd }}$ century (Mirdita, 1981, p. 270 № 353 (47). During the construction of Raška-Mitrovica railroad, at the very start of the stop for Kosovska Mitrovica, four votary statues were found. The inscription on the first statue $(0,88 \times 0,34 \times$ 0,28 м) says (Вулић, 1931, p. 81 № 208): I(ovi) o(ptimo) m(aximo) / Iun(oni) reg(inae) / Miner(vae) s(acrum) Aur(elius) / Saevinus / Procul(us) / b(ene)f(iciarius) co(n)s(ularis) / v(otum) l(ibens) p(osuit). The inscription dates back to the $3^{\text {rd }}$ century (ILJug $1393=$ CBFIR 606). The consular beneficiary inscription on the second statue $(0,84 \mathrm{x}$ 0,27 х 0,30 м) found in Kosovska Mitrovica says (Вулић, 1931, p. 90 № 209): I(ovi) o(ptimo) (!) sacr(um) / ex viso / M(arcus) Ulp(ius) / Viator / $b($ ene)f(iciarius) co(n)s(ularis) / ex fru(mentario). The inscription dates back to the second half of the $2^{\text {nd }}$ century (ILJug $1392=$ CBFIR 607). The consular beneficiary inscription on the third statue $(0,80 \times 0,32$ х 0,29 м) found in Kosovska Mitrovica says (Вулић, 1931, p. 91 № 210): Nemesi reg(inae) / sac(rum) pro / salutem (!) / dominor(um) / nn(ostrorum duorum) Augg(ustorum) / C(aius) Val(erius) Valens / b(ene)f(iciarius) co(n)s(ularis) leg(ionis) IIII Fl(aviae) / v(otum) l(ibens) l(aetus) me[ito] po[suit]. The inscription dates back to the end of the $2^{\text {nd }}$ century and the beginning of the $3^{\text {rd }}$ century (ILJug $1394=$ CBFIR $605)$. However, the consular beneficiary inscription found on the fourth statue in Kosovska Mitrovica $(0,88 \times 0,32 \times 0,28 \mathrm{M})$ says (Вулић, 1931, p. 91 № 211): Nemesi reg(inae) / sac(rum) / Ulp(ius) Martia(lis) b(ene)f(iciarius) co(n)s(ularis) / leg(ionis) IIII Fl(aviae) / v(otum) $s$ (olvit) l(ibens) $m$ (erito) The inscription dates back to the beginning of the $3^{\text {rd }}$ century (ILJug $1395=$ CBFIR 608). An ara was also found in Vučitrn $(0,82 \times 0,34 \times 0,34$ м) with the inscription (Вулић, 1931, p. 42 № 96). D(is) d(eabusque) / M(arcus) Aurelius / Marcianus / b(ene)f(iciarius) co(n)s(ularis) leg(ionis) / VII Cl(audiae) [[Sever(ianae)]]/ [[Alexan[drianae]] / v(otum) l(ibens) p(ersolvit) / Agricola et Clemente / co(n)s(ulibus). The inscription dates back to the $3^{\text {rd }}$ century (ILJug $1404=$ CBFIR 610). 
A significant ara was found on the aforementioned Lissus-Naissus road in Prizren $(0,42 \times 0,12 \times 0,17 \mathrm{M})$ with the inscription (Вулић, 1931, p. 135 № 325). [I(ovi) o(ptimo)] m(aximo) /[M]iner[vae Her]/[cu]li $\mathrm{Ne}[$ mesi] / [- - ]ul( - - ) Fi[rmus?] / b(ene)f(iciarius) [co(n)s(ularis)?] / [leg(ionis)] IIII Fl(aviae) f(elicis) [- - - / pos(uit). The inscription dates back to the $2^{\text {nd }}$ century (ILJug 1439; Mirdita, 1981, p. 261 № 300 (4). However, the authors of corpora for the beneficiary inscriptions for the province of Moesia Superior read it [I(ovi) o(ptimo)] m(aximo) / $\operatorname{Miner}($ vae) [Her]/[cu]li Ne[pt(uno)] / [- - - I]ul(ius) Fl[avius?] / b(ene)f(iciarius) [co(n)s(ularis)]/[leg(ionis)] IIII Fl(aviae) [fel(icis)]/[-- - ] (CBFIR 597). As we already said, significant is the previously found ara $(0,62 \times 0,25 \mathrm{M})$ with the inscription in Dobruždi or Škoza village that was later transfered to Žur village near Prizren (Вулић, 1931, p. 133, № 321). I(ovi) o(ptimo) m(aximo) / P(ublius) Ael(ius) Ing(enuus) b(ene)f(iciarius) / co(n)s(ularis) le/g(ionis) VII Cl(audiae) / v(otum) $s$ (olvit) l(ibens). The inscription dates back to the $2^{\text {nd }}$ century (ILJug $1444=$ CBFIR 598). According to the records, an ara was found on Lissus-Naissus road $(0,92 \times 171 \times 0,30 \mathrm{M})$ in Gračanica near Ulpiana, with the inscription: C(aius) Dom(itius) Licinianus / filius b(ene)f(iciarius) $\operatorname{co}\left(\right.$ n)s(ularis) / foro posuit. It dates back to the end of the $2^{\text {nd }}$ and the first half of the $3^{\text {rd }}$ century (CBFIR 580). An ara $(0,19 \times 0,25 \mathrm{M})$ with the inscription of the beneficiary with the rank of speculator from Ulpiana was also found (Вулић, 1931, p. 192, № 513). - - - / [- -]anu[s] / [sp]ecul(ator) leg(ionis) / [II]II Fl(aviae) S[ever(ianae)?] / $v$ (otum) [s(olvit) l(ibens) m(erito)] (ILJug 1419). The inscription dates back to the $2^{\text {nd }}$ century (Mirdita, 1981, p. 248 № 217 (16). As significant as all the previously mentioned is the inscription found in Batus village, south of Vučitrn (Čerškov, 1969, p. 57, 65; Мирковић, 1971, p. 266; Фидановски, 1989, p. 306; Mirdita, 2007, p. 36). I(ovi) o(ptimo) m(aximo) / [-]VPP / d(is) d(eabusque) et Gen[io] / stationis / pro s(alute) d(omini) $n$ (ostri) Imp(eratoris) / [[Severi Ale $]] /[[$ xandria $]]$ Aug(usti) / Valerianus / specul(ator) leg(ionis) IIII / [F](aviae) S(everianae) A(lexandrianae) v(otum) s(olvit) l(ibenis) $m$ (erito) Aug(usto) / Severo Alexand(ro) Aug(usto) / [II\} et Aufid(io) Marcello / [II co(n)s(ulibus)]. (CIL III 8173). The inscription dates back to the $3^{\text {rd }}$ century (Mirdita, 1981, p. 252 № 241 (40). Speculators were members of envoy’s personnel taken from the province's legions. Their main duty was to help the envoy in implementing justice into certain provinces and the area (Nelis-Clement, 2000, p. 117). They also performed intelligence duties, i.e. they were responsible for the flow of different pieces of information within, as well as the outside, of the province, 
which were sent to Rome as important messages to the emperor. They were the officers who had a highly significant role in the province administration and who were members of officium consularis (Čerškov, 1969, pp. 57, 65; Мирковић, 1971, p. 266; Mirdita, 1981, p. 252 № 241 (40); Фидановски, 1989, p. 306; Mirdita, 2007, p. 36). A votary ara was also found in Stari Kačanik near Kačanik with the consular beneficiary inscription (Evans, 1885, p. 74 fig. 39; Čerškov, 1969, p. 69; Papazoglu, 1969, p. 173; Mócsy, 1970, p. 243; Mócsy, 1974, p. 254; Mirdita, 2007, p. 29). Deo / Andino / sac(rum) Tib(erius) / Cl(audius) Certus / b(ene)f(iciarius) co(n)s(ularis) leg(ionis) VII / Cl(audiae) v(otum) s(olvit) l(ibens) $m$ (erito) / Clem(ente) et Prisc(o) co(n)s(ulibus). The inscription dates back to the $2^{\text {nd }}$ century (CIL III $8184=$ ILJug $1430=$ CBFIR 581).

CONCLUSION As we can see, beneficiarii consularis legionum, mostly beneficiarius legionis VII Claudiae and legionis IV Flaviae, were the most numerous in Kosovo and Metohija (Moesia Superior), but there are those whose legions were not mentioned. The aforementioned inscriptions prove that the consular beneficiary stations were found mostly along the main roads, on significant road intersections, and mine areas in this region. It is thought that smaller military units were situated in these stations whose main duty was to ensure the road safety and to control the transport of goods. Apart from this, it is believed that one of the duties of these consular beneficiaries was to collect the taxes. Consular beneficiaries were low-level officers among the envoy's personnel who were in charge of smaller military units in stations on the roads. The beneficiary stations were very frequent on the roads in the south of the province of Moesia Superior (Kosovo and Metohija) and the beneficiary inscriptions are more frequent when compared to the other parts and roads in the province. It is presumed that the consular beneficiary inscriptions, i.e. the beneficiaries from VII Claudia legion near Novi Pazar were responsible for the discovery of an unknown station located around the place where the epigraph statue was found or near the city itself. It is believed that the reason for placing beneficiary stations near Novi Pazar was the fact that the road led to the southeast and to the mine area called Rogozna and DD municipium (today's Sočanica). Many traces of the mine ore exploitation in the ancient times were discovered near Novi Pazar and Kosovo. There were rich deposits of copper, iron, and silver in Rogozna and Kopaonik. It is therefore believed that the frequency of the consular beneficiary 
stations was higher on the roads in the south of Moesia Superior (Kosovo and Metohija) beacuse of the need to protect the roads and transport of ores from the robbers. The military unit near Slatina also protected the road which connected mines near Sočanica with the main road. A few consular beneficiary inscriptions were found between Kosovska Mitrovica and Vučitrn and that is why there is a possiblity that an intersection of the aforementioned main roads was there (Narona-Novi Pazar-Skoplje, Lissus-Naissus) or the possiblity that the local roads intersected with main roads. Many significant local roads were interconnected with the road between Kosovska Mitrovica and Kačanik. The beneficiary station near Kačanik protected the entrance into the Kačanik ravine and customs station near today's Runjevo. VII Claudia legionaries near Škoza village controled the crossing over the Beli Drim river. It is believed that the road which crossed Drim near Škoza village probably went through today's Prizren and the beneficiary inscription from the second Moesia Superior legion, IV Flavia, was left by those who lived in the station there. All the epigraph beneficiary statues from the south of Moesia Superior date back to the end of the $2^{\text {nd }}$ and the middle of the $3^{\text {rd }}$ century.

\begin{tabular}{lll}
\hline ABBREVIA- & ANU BiH & Akademija nauka i umjetnosti Bosne i Hercegovine, Sarajevo. \\
TIONS & ZPE & Zeitschrift für Papyrologie und Epigraphik, Bonn. \\
& ILJug & Inscriptiones Latinae quae in Iugoslavia inter annos MCMII et \\
& MCMLXX repertae et editae sunt, Ljubljana. \\
& It. Ant. & Itinerarium Antonini, Berlin. \\
SKA & Српска краљевска академија, Београд. \\
CBI & Centar za balkanološka ispitivanja, Sarajevo. \\
CIL & Corpus Inscriptiones Latinarum, Berolini. \\
CBFIR & Corpus der griechischen und lateinischen Beneficiarier \\
& Inschriften des Römischen Reiches, Stuttgart. \\
& Tab. Peut. & Tabula Peutingeriana. Sttutgart.
\end{tabular}

SOURCES

Itinerarium Antonini, (1848). Itinerarium Antonini Augusti et Hierosolymitanum. Berlin: ed. G. Parthey / M. Pinder.

Itineraria Romana, (1916). Römische Reisenwege an der Han Der Tabula Peutingeriana. Sttutgart: ed. C. Müller.

Corpus Inscriptionum Latinarum, (1873). Consilio et auctoritate Academiae litterarum regiae. Berolini: Borussicae editum, ed. Th. Mommsen, Voll. III. 
Egon Schallmayer, Kordula Eibl, Joachim Ott, Gerhard Preuss, Esther WitkopfI, (1990). Der römische Weihebezirk von Osterburken I. Stuttgart: Corpus der griechischen und lateinischen Beneficiarier Inschriften des Römischen Reiches.

Šašel, A. et J., (1963). Inscriptiones Latinae quae in Iugoslavia Inter annos MCMXL et MCMLX repertae et editae sunt. Ljubljana: Situla 5, Narodni muzej Slovenije.

Šašel, A. et J. (1986). Inscriptiones Latinae quae in Iugoslavia inter annos MCMII et MCMXL repertae et editae sunt. Ljubljana: Situla 25, Narodni muzej Slovenije.

REFERENCES Вулић, Н. (1931). Антички споменици наше земље. Сйоменик СКА, LXXI, 133-135, 179-182, 208-211, 213-215, 274, 321, 325.

Glavaš I. (2013). Zavjetni žrtvenici iz stanice konzularnih beneficijara u Balinoj glavici. U: V. Kapitanović (ur.), Kultovi mitovi i vjerovanja u Zagori (Unešić 14. Prosinac 2012), Split, 33-75.

Glavaš, I. (2015). Stanica beneficijarija u Novama. Izdanja Hrvatskog arheološkog društva, 29, 27-40.

Glavaš, I (2016). Konzularni beneficijariji u rimskoj provinciji Dalmaciji. Mala biblioteka Godišnjaka zaštite spomenika kulture Hrvatske, sv. 17, 1-48.

Dise, R. (1995). Reassessment of the Function of Beneficiarii Consularis. The Ancient History Bulletin, 9/2, 72-85.

Dise, R. (1996). The Beneficiarii Procuratoris of Celeia and the Development of the Statio Network. ZPE, 113, 286-292.

Dise, R. (1997). Variation in Roman Administrative Practice: the Assignments of Beneficiarii Consularis. ZPE, 116, 284-299.

Domaszevski, A. (1895). Die Religiondes römischen Heeres. Westdeutsche Zeitschrift für Geschichte und Kunst, 14, 1-124.

Domaszewski, A. (1902). Die Beneficiarerposten und die romischen Strassennetze. Westdeutsch Zeitschrift fur Geschihte und Kunst, XXI/2, 158-211.

Domaszewski, A. (1904). Le stazione dei Beneficiarii e lareti stradali romane nell' Illurikum. Bullettino di archeologia e storia dalmata, XXVII, 14-17.

Evans, A.J. (1885). I.-Antiquarian Researches in Illyricum, III, and IV. Archaeologia, 49(01), 1-168. doi:10.1017/s0261340900001788

Марић, Р. (1956). Ситни прилози из археологије и епиграфике. С̄̄аринар, н.c. V-VI (1954-1955), 356-362. 
Matijević, I. (2012). O salonitanskim natpisima konzularnih beneficijarija iz legije Desete gemine (legio X Gemina). Vjesnik za arheologiju i povijest dalmatinsku, 105, 67-82.

Mirdita, Z. (1981). Antroponimia e Dardanisë në kohën romake. Prishtinä: Rilindija.

Mirdita, Z. (2015). Dardanci i Dardanija u antici. Zagreb: Hrvatski institut za povijest.

Мирковић, М. (1971). Бенефицијарна станица код Новог Пазара. Živa antika, god. XXI, sv. 1, 263-271.

Mirković, M. (1991). Beneficiarii Consularis an the New Outpost at Sirmium. u: Roman Frontier Studies, XV, (ur.) Valerie Maxfied i Michael Dobson, Exeter, 252-256.

Mócsy, A. (1970). Moesia Superior - Gesellschaft und Romanisation in der römischen Provinz Moesiam Superior. Budapest: Akademiai Kiadó.

Mócsy, A. (1974). Pannonia and Upper Moesia. A History of the Middle Danube Provinces of the Roman Empire. London - Boston: Routledge \& K. Paul

Mcmullen, R. (1963). Soldier and civilian in the Later Roman Empire. Cambridge, Mass: Harvard University Press.

Nelis-Clement, J. (1994). Le monde des dieux chez les beneficiarii. Der römische Weihebezirk von Osterburken II, Kolloquium 1990 und paläobotanische-osteologische Untersuchungen, (ur.) Egon Schallmayer, Stuttgart, 251-260.

Nelis-Clement, J. (2000). Les Beneficiarii: Militaires et administrateurs au service de l'empire. Paris-Bordeaux, Maison de l'Archéologie, Université Michel de Montaigne.

Ott, J. (1995). Die Beneficiarier. Stuttgart.

Papazoglu, F. (1969). Srednjobalkanska plemena u predrimsko doba. ANUBiH, knj. XXX, CBI, knj. 1, ANUBiH.

Папазоглу, Ф. (1988). Илирска и дарданска краљевина: поријекло и развој, структура, хеленизација и романизација. У: М. Гарашанин, (прир. и ур.), Илири и Албанц̧и, (стр. 145-173). Београд: САНУ.

Rankov, B (1987). The Beneficiarii Consularis in the Western Provinces of the Roman Empire. Oxford.

Rankov, B (1999). The governor's men: the officium consularis in provincial administration. The Roman army as community (Including papers of a conference held at Birkbeck College, University of London on 11-12 January, 1997). Journal of Roman archaeology, Supplementary series number 34, (ur.) Adrian Goldsworthy i Ian Haynes, London, 15-35. 
Schallmayer, E (1991). Zur Herkunft und Funktion der Beneficiarier. Roman Frontier Studies, XV, (ur.) Valerie Maxfied i Michael Dobson, Exeter, 400-406.

Ферјанчић, С. (2010). Vota solverunt libentes merito. Prilog izučavanju religije rimske vojske u Gornjoj Meziji. Zbornik Matice srpske za klasične studije, 12,133-147.

Фидановски, С. (1989). Римски и рановизантијски период. У: Н. Тасић

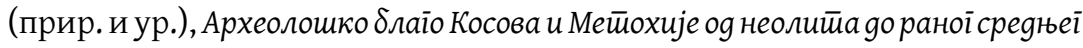
века, I-II, (стр. 258-349). Београд: САНУ - Музеј у Приштини.

Filow, B. (1906). Die Legionen der Provinz Moesia von Augustus bis aufDiokletianus. Leipzig.

Hirschfeld, O. (1891). Die Sicherheitspolizei im römischen Kaiserreich. Sitzungsberichte der königlichen Preussischen Akademie der Wissenschaften zu Berlin, Berlin, 845-877.

Caver, P. (1881). De muneribus militaribus centurionatu inferioribus - De Beneficiariis. Ephemeris epigraphica corporis inscriptionum latinarum supplementum edita iussu Instituti archaeologici Romani, V, 379-401.

Čerškov, E. (1969). Rimljani na Kosovu i Metohiji. Beograd: Arheološko društvo Jugoslavije.

ГЛИГОР М. САМАРџИЋ

УНИВЕРЗИТЕТ У ПРИШТИНИ С ПРИВРЕМЕНИМ СЕДИШТЕМ

У КОСОВСКОЈ МИТРОВИЦИ, ФИЛОЗОФСКИ ФАКУЛТЕТ

КАТЕДРА ЗА ИСТОРИЈУ

РЕЗИМЕ

О БЕНЕФИЦИЈАРСКИМ НАТПИСИМА СА ЈУГА ПРОВИНЦИЈЕ ГОРњЕ МЕЗИЈЕ (ПРИМЈЕРИ СА КОСОВА И МЕТОХИЈЕ)

У раду се презентују подаци о станицама конзуларних бенефицијара са југа провинције Горње Мезије (Косово и Метохија). На овом подручју најбројнији су били beneficiarii consularis legionum, и то beneficiarius legionis VII Claudiae и legionis IV Flaviae, али ठило је и оних уз које се појам „легија“ не спомиње. Натписи са Косова и Метохије потврђују да су се станице конзуларних ठенефицијара (локалних полицијских официра) налазиле дуж главних комуникацијских праваца, на важним саобраћајним раскрсницама и у рудним областима. Сматра се да су у овим станицама биле смјештене мање посаде војника чији је основни

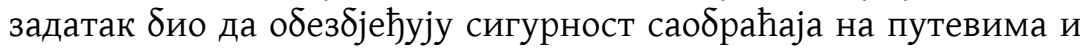
контролишу транспорт робе. Поред тога, њихова обавеза била је 
и прикупљање и чување пореза у натури. На путевима на југу провинције Горње Мезије (Косово и Метохија) бенефицијарне станице ठиле су веома честе, а натписи бенефицијара бројни у односу на друге дијелове и путеве у провинцији. Сматра се да је разлог постављања бенефицијарне станице у околини Новог Пазара био у томе што је пут водио даље на југоисток према рудничкој области Рогозне и муниципијуму DD (данашња Сочаница). Наиме, на локалитетима око Новог Пазара и у косовској области откривени су бројни трагови експлоатације руде у антици и отуда је густина станица конзуларних ठенефицијара на путевима на југу Горње Мезије настала из потребе обезбјеђења саобраћаја и транспорта из рудника од разбојника. Такође, војна посада код Слатине штитила је пут који је повезивао руднике код Сочанице са магистралном саобраћајницом. Између Косовске Митровице и Вучитрна нађено је неколико натписа конзуларних ठенефицијара, па постоји могућност да се ту налазила раскрсница два главна пута (Нарона-Нови Пазар-Скопље, Лисус-Наисус) или су се пак са главном комуникацијом укрштали локални путеви. На траси пута између Косовске Митровице и Качаника увезивао се низ путева локалног значаја. Бенефицијарна станица код Качаника обезбјеђивала је улаз у Качаничку клисуру и царинску станицу код данашњег Руњева. Припадници легије VII Claudia код села Шкоза контролисали су прелаз преко Белог Дрима. Сматра се да је траса пута која је код овог села прелазила Дрим вјероватно ишла преко данашњег Призрена те да натпис ठенефицијарија друге Горњомезијске легије, IV Flavia, потиче од посаде станице на том мјесту. Сви епиграфски споменици ठенефицијарија са југа Горње Мезије датују се од краја II до средине III вијека.

КљУчнЕ РЕчи: енефицијари; натписи; легије; Горња Мезија; Косово и Метохија.

Овај чланак је објављен и дистрибуира се под лиценцом Creative Commons Ауторство-Некомерцијално Међународна 4.0 (CC BY-NC 4.0 |

https://creativecommons.org/licenses/by-nc/4.0/).

This paper is published and distributed under the terms and conditions of the Creative Commons Attribution-NonCommercial International 4.0 licence (CC BY-NC 4.0 | https://creativecommons.org/licenses/by-nc/4.0/). 